\title{
REFLECTING ON THE RULE OF LAW, ITS RECIPROCAL RELATION WITH RIGHTS, LEGITIMACY AND OTHER CONCEPTS AND INSTITUTIONS
}

\author{
Samuel J.M. Donnelly*
}

\section{INTRODUCTION}

For many years I have admired my colleague, Dr. Richard Schwartz, ${ }^{1}$ and his project of relating social science to the study of law. Dr. Richard Schwartz is not only an inspired social scientist but a very fascinating and friendly partner in deep conversation. After many discussions, I also admire his project of relating the study of law and social science to the task of establishing the rule of law and bringing greater peace and justice to our troubled world. From the perspective of a lawyer who reflects philosophically on legal decision making and in celebration of my friend, Dr. Richard Schwartz, I would like to contribute some modest thoughts to that very important project.

We must recognize, of course, the great progress which has been made in the establishment of the world rule of law since the important seventeenth century developments in International Law, which so fascinate Dr. Schwartz. ${ }^{2}$ Since the end of World War II, we have had

\footnotetext{
* Professor of Law, Syracuse University College of Law, LL.B. Harvard University, LL.M. New York University. Professor Donnelly thanks his research assistant Erik Helbing for his work on the footnotes. This paper was prepared for a conference on the World Rule of Law presented at the Syracuse University College of Law to honor Dr. Richard Schwartz on the occasion of his retirement.
}

1. Professor Richard Schwartz holds a B.A. and Ph.D. in sociology from Yale University. He is currently the Ernest I. White Research Professor of Law at Syracuse University College of Law; he additionally is a Professor of Sociology at Syracuse University. Prior to teaching at Syracuse, Professor Schwartz taught on the law and sociology faculties at Northwestern and Yale Universities, as well as served as Dean of the law school at SUNY Buffalo. Professor Schwartz has numerous publications to his credit including: (1) Natural Law, in INTERNATIONAL ENCYCLOPEDIA OF THE SOCIAL BEHAVIORAL SERVICES; (2) Human Rights in an Evolving World Culture, in HUMAN RIGHTS IN AFriCA: Cross-Cultural Perspectives (A. A. An-Naim and F.M. Deng, eds., Brookings 1990); (3) Law and Normative Order, in LAW AND THE SOCIAL ORDER (L. Lipson and S. Wheeler, eds., Russell Sage Foundation 1986).

2. See William Bradford, Barbarians at the Gates: A Post-September $11^{\text {th }}$ Proposal to Rationalize the Laws of War, 73 Miss. L.J. 639, $702-03$ (2004). Subsequent to the Treaty of Westphalia in 1648, secular international law developed. Id. This development is demonstrated by the treatment of Prisoners of War who became wards of the capturing sovereign as opposed to prizes of the capturing soldier. Id. Moreover, by the eighteenth century, Prisoners of War could be confined or sold into slavery, but they were no longer reflexively put to death. Id. 
one of the great periods in the development of international law and the global rule of law. ${ }^{3}$ The development of the European Union ${ }^{4}$ and the progress made under the European Covenant on Human Rights ${ }^{5}$ has been particularly remarkable.

When bringing social science to the study of law, understanding the role of law in the process of social change is central. The great American example of social change influenced by law begins, of course, with the end of our Civil War, the freeing of the slaves, and continues through the establishment of segregation, the attacks upon it, desegregation and the development of affirmative action.

May I suggest that another very important sequence of legal and social changes is the development and recognition of human rights in the European Union since World War ${ }^{-1}{ }^{6}{ }^{6}$ That momentous development is worth studying from the perspective of law and social science. In the first part of the following presentation I would like to offer some observations on those two examples of law and social change over a significant period of time. Using those two examples as illustrations, I want to then reflect from a philosophical perspective on a series of concepts that I think are important in understanding the role of law in social change.

In my recent book, A Personalist Jurisprudence, The Next Step, ${ }^{7}$ I reflected upon the interrelation between a series of concepts including the rule of law and its relation to legal protection of rights; the language and uses of rights; legitimacy; primary social goods, a concept helpful in understanding rights; horizons; crossing horizons and the use of

3. See, e.g., Convention on the Prevention and Punishment of the Crime of Genocide, opened for signatures Dec. 11, 1948, 78 U.N.T.S. 277; International Covenant on Civil and Political Rights, entered into force Mar. 23, 1976, 999 U.N.T.S. 171 [hereinafter ICCPR]; Geneva Convention Relative to the Protection of Civilian Persons in Time of War, Aug. 12, 1949, 6 U.T.S. 3516, 75 U.N.T.S. 287.

4. The European Union was created by a treaty completed in 1992 by Belgium, Denmark, France, Germany, Greece, Ireland, Italy, Luxembourg, the Netherlands, Portugal, Spain, and the United Kingdom. See Treaty on European Union, Feb. 7, 1992, 31 I.L.M. 253.

5. European Convention for the Protection of Human Rights and Fundamental Freedoms, entered into force Sept. 3, 1953213 U.N.T.S. 221 [hereinafter European Convention].

6. The European Union, created in 1992, is a relatively new entity. The author does not wish to suggest human rights advances have not taken place within Europe prior to the creation of the European Union as demonstrated by the European Convention of Human Rights in 1950.

7. Samuel J. M. Donnelly, A Personalist Jurisprudence, the Next Step: A Person-Centered Philosophy of LAW for the Twenty-First Century (Carolina Academic Press 2003). 
rights to hammer on foreign horizons, or the establishment of rights across horizons; and analysis of the point of view from which statements about rights are made.

In A Personalist Jurisprudence, The Next Step, I discuss, among other matters, how these concepts and their interrelation can be used to understand and construct a method for judicial decision making. The same concepts can be used from the perspective or point of view of a law reform attorney to discuss strategies for law reform. ${ }^{8}$ In this paper, I want to offer those concepts and their interrelation from the perspective of a legal philosopher and lawyer as a possibly helpful means for analyzing the gradual establishment internationally and throughout the world of the rule of law accompanied by the advance of human and civil rights. Perhaps these concepts also may prove helpful to social scientists as well as legal philosophers in discussing and understanding the role of law in the process of social change. That social change may include the gradual establishment of the rule of law both within individual countries and internationally. Part of my argument is that advances in the protection of individual rights also support the developing rule of law and vice versa. I want to organize that discussion around an analysis of the language and uses of rights including how rights are used in the process of social change and how the pursuit of rights relates to establishing the rule of law. What do we mean, then, by the rule of law? And how is the rule of law related to legal protection or protection by courts of individual rights? In the second part I want to address those questions.

Then, in Part III, I should address what we mean by rights. How do we discern fundamental rights and why should we recognize those rights? How do rights come to be perceived as legitimate? Legitimacy, rights and primary social goods is the topic of Part III. Primary social goods is a concept I have taken from John Rawls and adapted to my own understanding. Rawls has an important discussion of the relations between primary social goods and the principles of justice. ${ }^{9}$

In my understanding, rights always are perceived within horizons and from a point view. In Part IV, I want to discuss rights, horizons and point-of-view analysis. In the international sphere, one could argue that a number of controversies arise because particular rights or questions concerning the existence of rights are perceived within the horizons of

8. See DONNELLY, supra note 7, at 283-89.

9. See John RAWLS, A THEORY OF JUSTICE 396-99, 433-39, 447 (Harvard Univ. Press 1971); see also Samuel J. M. Donnelly, Towards a Personalist Jurisprudence: Basic Insights and Concepts, 28 LOY L.A. L. REV. 547, 587-88 (1995). 
different cultures. An advocate for rights may have to cross or penetrate foreign horizons in order to persuade persons of another culture to accept certain rights.

To accomplish law reform, to produce social change, the advance of rights and the rule of law may require those studying or seeking to promote those changes to understand horizons and the art of crossing horizons. Since rights, as I perceive them, always are understood within a horizon and from a point of view, those promoting or studying social change, law and rights should strive to understand the use of rights and the language of rights as tools for crossing horizons, for hammering on foreign horizons or encouraging others to cross horizons. Rights traditionally may be understood as remedies offered by law, as conclusions drawn within a legal system or in more advanced theory as reasons for decisions, or reasons in the decision making process which will trump competing reasons. From the perspective of one studying or promoting law reform, I am suggesting that we understand how rights are used as tools, as goals to be pursued in the law reform process, as means for achieving those goals, and as political resources. ${ }^{10}$ In Part V then, I will address the language and uses of rights: rights as tools in the process of social change.

Finally, I would like to recognize Dr. Schwartz's admiration for natural law not only for its contributions to the seventeenth century development of international law but also as a warehouse of resources for the establishment of the world rule of law and the recognition of human rights. Using the concepts developed in the previous discussion, I want to reflect on what we mean by, and how we use, natural law and how it might contribute to understanding and advancing human rights, the rule of law and the process of social change, which may lead to their acceptance.

When reflecting on these topics, I will be commenting from the perspective of a lawyer and philosopher of law. That precisely is not the perspective of a social scientist. From my ignorance, I would describe a social scientist as concerned with description and explanatory theory. Some explanatory theories are particularly powerful and grand. Lawyers hardly ever seek explanatory theories of the kind admired by social scientists and normally do not emphasize description as a primary task. Lawyers are concerned with decision making and persuading decision makers. Understanding law from the point of view of the

10. See Donnelly, supra note 7, at 254-60; see also SAMUEL J. M. DOnNELly, THE LANGUAGE AND USES OF RIGHTS: A BIOPSY OF AMERICAN JURISPRUDENCE IN THE TWENTIETH CENTURY 1 (Univ. Press of America 1994). 
decision maker is central to a lawyer's work and central to legal philosophy as practiced in America. ${ }^{11}$ To the extent that social scientists and legal philosophers provide lawyers with reflections on decision making or tools for decision making they may be very helpful to intelligent practicing attorneys.

I want to take the perspective of one performing that task in the following discussion. Promoting human rights and establishing the global rule of law is a task for statesmen and lawyers, as well as an academic subject to be examined from the perspective of legal philosophers and social scientists

\section{LAW AND SOCIAL CHANGE: GREAT EXAMPLES}

To study the promotion of human rights and the establishment of a world rule of law, we must think about social change both worldwide and in individual countries. We must also study the role of law in social change.

\section{A. Brown v. Board of Education}

The great example, studied by many social scientists, of the interaction of law and culture resulting, perhaps, in social change are the legal, political and cultural events and circumstances just prior to and following Brown v. Board of Education of Topeka, Kansas. ${ }^{12}$ Actually, that sequence of legal and cultural changes began almost two centuries before that great 1954 decision of the Warren Court.

Arbitrarily, I would select 1773 and the equally great decision of King's Bench in Somersett v. Stewart ${ }^{13}$ as the starting point for the falling dominos that led to the abolishment of slavery, desegregation and ultimately affirmative action in the United States. In Somersett, Lord Mansfield, the Chief Justice speaking for King's Bench in a habeas corpus case, freed a black slave, James Somersett, who was being held at his master's orders on a ship in the Thames for sale in Jamaica. $^{14}$ Mansfield found the return on the writ insufficient since there were no relevant laws, cases or statutes authorizing slavery in England. ${ }^{15} \mathrm{He}$ explained that slavery was too obnoxious to be

11. See DonNELly, supra note 7, at 74-83; see also RONALD DWORKIN, LAW's EMPIRE 154-55 (Belknap Press 1986).

12. 347 U.S. 483 (1954).

13. Somersett v. Stewart, 98 Eng. Rep. 499 (K.B. 1772).

14. See EDMUND HEWARD, LORD MANSFIELD 144 (Mary Rose Ltd. London 1979).

15. See C.H.S. FifoOt, LORD MANSFIELD 41 (Oxford Univ. Press 1936). 
established by custom. ${ }^{16}$ Given the common law doctrine of precedent, Mansfield in effect abolished slavery in England and freed 14,000 or 15,000 slaves. $^{17}$

A short law reform campaign preceded Somersett, largely conducted by a London radical, Granville Sharp, who had obtained the writ of habeas corpus for James Somersett from Lord Mansfield. ${ }^{18}$ More significant for the study of law and social change is the gradual fall of the dominoes after Somersett v. Stewart. That decision made in 1773 before our Declaration of Independence on July 4, 1776 would be considered binding precedent in most of our American States. ${ }^{19}$ Why then did slavery not immediately fall in the United States? Mansfield's decision in Somersett turned on the absence of legal authorization, either statutory or case law, for slavery. A number of our states particularly in the South had legislation regulating slavery. Nevertheless, Somersett v. Stewart was an important precedent, which gave legitimacy to the abolition movement in the United States, England and the British colonies. ${ }^{20}$

Duncan Kennedy describes "legitimacy power" as an important

16. See DoNNELLY, supra note 7, at 269.

17. HEWARD, supra note 14 , at 146-47.

18. Id. at $144-45$.

19. Available studies strongly suggest that the current consensus that "common law" was a technical reference to the rules of law and methods of procedure of the three royal courts at Westminster was not a consensus of 1791 or prior. In 1952, Chafee reviewed the scope of the unwritten law administered in the thirteen original colonies. He noted at least four recognized meanings of the phrase "common law:" (1) the systems of law "now prevalent in the United States and most of the British Commonwealth of Nations" in contrast with the civil law system "derived from Roman law;" (2) the "law common to all of England" in contrast with the law of local English jurisdictions; (3) "unwritten law in contrast with legislation;" and (4) the "law applied in the Courts of Common Pleas, King's Bench, and Exchequer" in contrast with that "applied in the Court of Chancery." See Richard E. Coulson, Is Contractual Arbitration an Unconstitutional Waiver of the Right to Trial by Jury in Oklahoma?, 16 OKLA. CITY U. L. REV. 1, 33-34 (1991)(citing Chafee, Colonial Courts and the Common Law, 68 Proceedings, MASS. Hist. Soc. 132 (1952)), reprinted in ESSAYS IN THE HISTORY OF EARLY AMERICAN LAW 53 (Univ. of North Carolina Press 1969). Compare Daniel J. Hulsebosch, The Ancient Constitution and the Expanding Empire: Sir Edward Coke's British Jurisprudence, 21 LAW \& HisT. REV. 439, 474-75 (2003) (Sir William Blackstone, whose Commentaries on the Law of England were read throughout the Atlantic world, maintained that the American colonies were "conquered or ceded countries" and "therefore the common law of England, as such, has no authority there; they being no part of the mother country, but distinct (though dependent) dominions." He accounted for any resemblance by supposing that the colonists had "copied the spirit of their own law from the original" and declared that they remained "subject ... to the control of parliament.").

20. See DONNELlY, supra note 7, at 267. 
element in social change through law. ${ }^{21}$ As our discussion proceeds, we should pay some attention to the notion and uses of legitimacy power.

In England, shortly after Somersett, Granville Sharpe ${ }^{22}$ began to use his newly acquired legitimacy power to attack the slave trade. In Somersett, Mansfield had been careful to abolish slavery only in England. He distinguished the slave trade, which was important to the commerce of England, and did not affect it. Granville Sharpe, however, persuaded a young member of parliament, who ultimately became Lord Wilberforce and one of the great figures in the war against Napoleon, to file a bill abolishing the slave trade. ${ }^{23}$ That bill was filed and ignored each year for twenty years until it was finally passed in 1807 , in the middle of the war against Napoleon. ${ }^{24}$ Stopping ships to search for illegal slaves was probably an aid in the blockade of Napoleonic France. It has been rightly remarked that an ideal coupled with an interest is a

21. See generally Duncan Kennedy, Freedom and Constraint in Adjudication: $A$ Critical Phenomenology, 36 J. Legal EduC. 518 (1986).

22. Granville Sharpe's activities in the English anti-slavery movement predate Somersett. For example, in 1765 as Granville was visiting his brother William in Mincing Lane he stumbled upon a poor black man by the name of Jonathan Strong. Strong was the property of David Lisle, an attorney from Barbados. One day Lisle in a fit of rage beat Strong over the head with the butt of a pistol, until Strong was almost blind. Because, a blind slave is of no value to his master, Lisle turned Strong onto the streets to die. Thereupon the Sharpe brother arranged for Strong's admittance to a local hospital, where he remained for four months. See HEWARD, supra note 14, at 140-42.

After his recovery Strong secured employment as an errand boy for an apothecary. One day by accident, Strong ran into his former master, who upon seeing Strong was of some value, sold Strong to James Kerr. Kerr arranges to kidnap Strong and have him imprisoned at Poultry Counter Prison, while he awaits a ship to transport Strong to the Indies. At this point Granville appears before Sir Robert Kite, Lord Mayor, to complain that Strong is imprisoned without a warrant. Kerr produced the bill of sale, and the Lord Mayor declared Strong to be the property of Kerr. Nevertheless, the Lord Mayor rules that not even a slave can be imprisoned without a warrant, and thus allowed Strong to walk out of the courtroom. Kerr proceeded to sue Granville for $£ 200$ for deprivation of property. These charges were later dropped. Id.

23. William Lord Wilberforce (1759-1833) was educated at the University of Cambridge. Lord Wilberforce was elected to Parliament in 1780, and embraced Evangelical Christianity in 1784. Lord Wilberforce emerged as the abolitionist movement in the House of Commons. In 1807, Lord Wilberforce secured enactment of a bill prohibiting the slave trade. In 1823, Lord Wilberforce was a founding member of the Anti-Slavery Society. In 1825 because of poor health, Lord Wilberforce was forced to resign from the House of Commons. The bill abolishing slavery passed one month after Lord Wilberforce's death. See 27 FunK \& WAGNALLS NEW ENCYCLOPEDIA 300-01 (1986).

24. In the United States, the slave trade could not be prohibited until 1808. See U.S. CONST. art. I $\S 9 \mathrm{cl}$. 1. In 1807 Congress passed an act to abolish the slave trade (but not the institution of slavery) on January 1, 1808. See An Act to Prohibit the Importation of Slaves Into Any Port or Place Within the Jurisdiction of the United States, From and After the First Day of January, in the Year of Our Lord One Thousand Eight Hundred and Eight, ch. XXII 3 Stat. 426-30 (1807). 
powerful political force.

The slave trade was effectively brought to a halt after England, and the United States agreed in the 1840's to joint patrolling of the coast of Africa by the British and American fleets. ${ }^{25}$ At that time, England was attempting to obtain toeholds on the coast of Africa. Again, we see the power of an ideal coupled with an interest.

In between those events at the Congress of Vienna, at the close of Napoleon's wars, the great powers of Europe agreed to the abolishment of the slave trade. ${ }^{26}$ Participation in the slave trade was thereafter added to piracy as a crime of international jurisdiction, crimes which could be prosecuted and tried by any nation. ${ }^{27}$ Please observe the gradual social change influenced by law leading towards the establishment of human rights and the rule of law. And note the importance of legitimacy power in that process.

The dominoes, of course, fell dramatically thereafter, first in the Caribbean, ${ }^{28}$ then the American South, ${ }^{29}$ and ultimately in Brazil. ${ }^{30}$ The

\section{See Webster-Ashburton Treaty, Aug. 9, 1842, U.S.-U.K., 8 Stat. 572.}

26. At the advent of the Congress of Vienna in 1815,800 petitions were presented to the British House of Commons to stop the international slave trade, this public pressure spurred the British government to press for action at Vienna. See Steve Charnovitz, Two Centuries of Participation: NGOs and International Governance, 18 MICH. J. INT'L L. 183, 192 (1997). However, the only agreement that could be achieved was a declaration condemning the slave trade. See Declaration of Eight Courts Relative to the Universal Abolition of the Slave Trade, Feb. 8, 1815, 63 Consol. T.S. 473. Nevertheless, numerous treaties were signed between individual nations concerning the slave trade. See, e.g., Treaty for the Abolition of the Slave Trade, Sept. 23, 1817, Gr. Brit.-Spain, 68 Consol. T.S. 45; Treaty at The Hague, May 4, 1818, Gr. Brit.-Neth., 68 Consol. T.S. 403; Declaration Respecting the Abolition of the Slave Trade, Nov. 28, 1822, Aus.-Fr.-Gr. Brit.-Prussia-Russ, 73 Consol. T.S. 31; Slave Treaty, Nov. 6, 1824, Gr. Brit.-Swed.-Neth., 75 Consol. T.S. 1.

27. See Convention on the High Seas, Apr. 29, 1958, art. 13, 13 U.S.T. 2376, 450 U.N.T.S. 90; RESTATEMENT (THIRD) OF FOREIGN RELATIONS § 404 (1987).

28. In 1791 the Blacks in Haiti entered into a full-fledged rebellion that would result in the creation of the State of Haiti and the abolition of slavery. In 1801 Toussaint Louventure proclaimed himself governor of St. Domingue (Haiti), and a constitution was passed abolishing slavery. In 1802 the French arrested and exiled Louventure to France where he died a year later. The Haitians then purchased their independence from France. After the assassination of Emperor Dessalines in 1806 the country split in half. In 1822 Jean Pierre Boyer invaded the eastern part of the island, unified the island, and abolished slavery. See Synopsis of Haitian History, available at http://www.discoverhaiti.com/history_summary.htm (last visited Apr. 29, 2005).

29. See U.S. ConST. amend. XIII, $\S 1$.

30. Slavery was abolished in Brazil in several stages. In 1871 the "Law of the Free Womb" freed all children born of a slave, but the master retain labor rights until the child reached the age of twenty-one. In 1885 the law freed all slaves over the age of 60 . In 1888 the "Golden Law" freed all remaining slaves without compensation to the owner. See From Slavery to Abolition in Nineteenth Century Brazil, at http://darkwing.uoregon.edu/ caguirre/381_14.html (last visited, Apr. 29, 2005). 
great drama, culminating in the abolishment of slavery, came to an end.

But then a new episode, a sequel, began as the American South replaced slavery with segregation through a long series of struggles culminating legally in Plessy v. Ferguson. ${ }^{11}$

Following Plessy, a new era of law reform began, not unrelated to Somersett $v$. Stewart $t^{32}$ and the abolishment of slavery. The great law reform campaign organized by the NAACP beginning in 1929 gradually, case by case, established legitimacy power for desegregation. ${ }^{33}$ The work of their lawyers, however, was not the only force leading in 1954 to Brown v. Board of Education of Topeka, Kansas. ${ }^{34}$

Arguably the era of law which William Wiecek describes as legal classicism came to an end with Franklin Roosevelt's appointments to the United States Supreme Court in the late 1930's. ${ }^{35}$ At the time of Brown v. Board of Education, many of the Roosevelt appointees were still serving on the Court. ${ }^{36}$ In my book, A Personalist Jurisprudence, The Next Step, I describe some of the forces leading to Brown as follows:

The period between 1937 and 1954 was a tumultuous time including the end of the Great Depression, the Second World War, the Holocaust, the Korean War and the beginning of the Cold War confrontation with Russia. Arguably these experiences changed our national outlook and understanding. On racial questions, the experience of Americans in the armed forces, Truman's desegregation of the military and the shock of the Holocaust prepared our

31. 63 U.S. 537 (1896).

32. 98 Eng. Rep. 499 (K.B. 1772).

33. See, e.g., Gaines v. Canada, 305 U.S. 337 (1938) (Missouri must offer AfricanAmericans substantially equal legal education, effectively requiring Missouri to admit African-Americans to a white school); see also Sipuel v. Board of Regents of Oklahoma, 332 U.S. 631 (1948) (State law schools cannot discriminate against African-Americans); Steele v. Louisville \& Nashville Ry. Co., 323 U.S. 192 (1944) (Union representatives under the Federal Railway Act cannot discriminate in representation of members on the basis of race); Shelley v. Kraemer, 334 U.S. 1 (1948) (Racial restrictive covenants in private housing violate the Equal Protection Clause of the Fourteenth Amendment).

34. 347 U.S. 483 (1954).

35. William Wiecek, The lost World of Classical Legal Thought: LaW and IDEOLOGY IN AMERICA, 1886-1937 (Oxford Univ. Press 1998).

36. See DonNelly, supra note 7, at 144. The Roosevelt appointees to the Court at the time Brown was decided were in order of appointment: Hugo Black, Stanley Reed, Felix Frankfurter, William Douglas, and Robert Jackson. Id. 
national culture for a changed position on race. Legally the demise of legal classicism and the advance of pragmatic instrumentalist thought was helpful. The great law reform campaign conducted by lawyers for the NAACP beginning in 1929 had established a series of useful precedent. ${ }^{37}$

The process of social change leading to and following from Brown has been the subject of many social science studies. ${ }^{38}$ Controversially, the Brown Court relied on social science studies including Gunnar Myrdal's An American Dilemma, in support of its decision. ${ }^{39}$ In contrast, the quality of the reasoning process in Brown has been the subject of many competing works of legal philosophy. The quarrels over Brown may be the heart of what I describe as the modern great quarrel over method. ${ }^{40}$

From the perspective of a legal philosopher questions such as how should Chief Justice Warren have justified his decision in Brown, and is the decision justifiable, are the fascinating questions. From the perspective of a law reformer, examining the strategies of the NAACP and Thurgood Marshall is an important study. ${ }^{41}$ A very helpful work of social science derived from the effort is Stuart Scheingold, The Politics of Rights. ${ }^{42}$ What I am suggesting is that social scientists who want to contribute to the advance of human rights follow the example of Scheingold. Legal philosophers creating or criticizing decision making methods should struggle to understand the relation between social forces and the work of decision makers.

37. See DONNELLY, supra note 7, at 144-45.

38. See Stuart A. Scheingold, The Politics of Rights: Lawyers, Public Policy, AND Political Change 4-6 (Yale Univ. Press 1974).

39. The studies relied on by the Court to assess the effect of school segregation include inter alia: "[1] K. B. Clark, Effect of Prejudice and Discrimination on Personality Development (Midcentury White House Conference on Children and Youth, 1950); [2] Witmer and Kotinsky, Personality in the Making (1952), c. VI; [3] Deutscher and Chein, The Psychological Effects of Enforced Segregation: A Survey of Social Science Opinion, 26 J.PsYCHOL. 259 (1948); [4] Chein, What are the Psychological Effects of Segregation Under Conditions of Equal Facilities?, 3 INT. J. OPINION AND ATtITUDE RES. 229 (1949); [5] Brameld, Educational Costs, in Discrimination and National Welfare (MacIver, ed., 1949), 44 48; Frazier, The Negro in the United States (1949), 674-681. And see generally Myrdal, An American Dilemma (1944)." Brown, 347 U.S. at 494-95 n.11 (italics added).

40. See DoNNELly, supra note 7, at 153.

41. See id. at 283-89.

42. SCHEINGOLD, supra note 38. 


\section{B. European Human Rights}

On October 29, 2004, the members of the European Union took a further major step towards advancing human rights and the rule of law on their continent. They signed a Constitution for the European Union. $^{43}$ The new Constitution contained a list of fundamental rights: life, integrity of the person, marriage, freedom of thought, conscience, religion, expression and assembly, education, work, asylum, equality, equality between men and women, social security, health care, environmental and consumer protection, petition, fair trial and presumption of innocence. $^{44}$

The signing of the new Constitution is the latest in a long series of events starting after the Second World War with establishment of the United Nations. The 1945 U.N. Charter, in Article 55, authorized the United Nations to "promote ... universal respect for and observance of human rights." $" 45$ In 1946, the Commission on Human Rights was created under Article 68 of the U.N. Charter ${ }^{46}$ to draft human rights treaties implementing Article 55. In 1948, the General Assembly contributed the Universal Declaration of Human Rights as a means for defining the rights to be promoted and respected under Article 55 of the U.N. Charter. The Universal Declaration of Human Rights ${ }^{47}$ was not a treaty and not legally binding on member States. ${ }^{48}$ However, two basic treaties were adopted in 1966 and offered for ratification to member States, The International Covenant on Civil and Political Rights ${ }^{49}$ and the International Covenant on Economic, Social and Cultural Rights. ${ }^{50}$

43. See Graham Bowley, Heads of State Sign the European Union's First Constitution, N.Y. TiMES, Oct. 30, 2004, at A3. 2004).

44. See generally Treaty Establishing A Constitution For Europe, CIG 87/04 (Aug. 6,

45. U.N. CHARTER art. 55, para. c.

46. Article 68 of the U.N. Charter provides "The Economic and Social Council shall set up commissions in economic and social fields and for the promotion of human rights, and such other commissions as may be required for the performance of its functions." Id. at art. 68 .

47. The Universal Declaration of Human Rights, G.A. Res. 217A, U.N. GAOR, 3d Sess., Supp. No. 13, at 71, U.N. Doc. A/1810 (1948).

48. Article 11 of the United Nations Charter mandates that any matter brought before it where action is necessary must be referred to the Security Council by the General Assembly. U.N. CHARTER art. 11, para. 2; see also J.L. BRIERLY, THE LAW OF NATIONS: AN INTRODUCTION TO THE INTERNATIONAL LAW OF PEACE 110 (Sir Humphrey Waldock ed., 6th ed. Oxford Press 1963) (resolutions passed by the United Nation's General Assembly are not binding on member states).

49. ICCPR, 999 U.N.T.S. 171.

50. International Covenant on Economic, Social, and Cultural Rights, opened for signature Dec. 19, 1966, 993 U.N.T.S. 3. 
In the meantime, the Council of Europe, which was created in 1949, during 1950 offered its member States the European Convention for the Protection of Human Rights and Fundamental Freedoms, ${ }^{51}$ which became effective after ratification in 1953. This treaty has been ratified by all the members of the Council of Europe. The European Convention on Human Rights initially was enforced by the European Commission on Human Rights. Cases which could not be settled by the persuasive power of the European Commission on Human Rights would be referred to the Council of Europe's committee of ministers. Alternatively, member States or the Commission could refer cases to the European Court of Human Rights whose decisions would be enforced by the Commission on Human Rights. ${ }^{52}$

A new and more powerful European Court of Human Rights was established in November $1998 .^{53}$ Now, individuals with human rights complaints may proceed directly in the Court of Human Rights. One should note, of course, that the Council of Europe should be distinguished from the European Union and the Court of Human Rights from the Court of Justice of the European Union.

The European Convention on Human Rights has had wide impact on the advance of human rights in Europe. That influence was summarized in 1994 as follows:

In Austria where the Convention has the rank of

51. European Convention, 213 U.N.T.S. 221.

52. Prior to the adoption of Protocol 11 in 1998 the European Court of Human Rights operated as follows: (1) The European Commission on Human Rights considered the admissibly of the case. (2) If the case was admissible, the Commission determined the facts and attempted to secure a friendly settlement. (3) The Commission prepared a report regarding unsettled cases, including a finding of facts and its opinion with regard to violations. This report went to the Committee of Ministers of the Council of Europe. During the next three months the Committee, Commission, or any interested state party could refer the case to the Court. N.B. individual claims came before the court only through the Commission because only states and the Commissions could bring cases to the Court. Since the adoption of Protocol 11 in 1998 the European Court of Human Rights hears all cases alleging violations of individual rights, the function of the Commission and the Commission itself has been terminated. See Linda A. Malone, InTERnational Human RiGHTS 57-58 (West Group 2003).

53. Prior to 1998 the Committee of Ministers was an alternative to the European Court of Human Rights as a body for determining breaches of the European Covenant of Human Rights. In 1998 the State members of the Council of Europe decided in Protocol 11 to the European Covenant of Human Rights to abolish this role. As such, the European Court of Human Rights is currently the only body competent to determine breaches of the European Covenant on Human Rights. See Robin R. Churchill \& Urfan Khaliq, The Collective Complaints System of the European Social Charter: An Effective Mechanism for Ensuring Compliance with Economic and Social Rights, 15 EUR. J. INT'L. L. 417, 455 (2004). 
constitutional law, the Code of Criminal Procedures has had to be modified as a result of case-law in Strasbourg; so too the system of legal aid fees for lawyers. In Belgium, amendments have been made to the Penal Code, its vagrancy legislations and its Civil Code to insure equal rights to legitimate and illegitimate children. In Germany modifications that bring legislation better into line with the Convention's provisions have also been made ...

In the Netherlands where most of the Convention's selfexecuting substantive provisions are endowed with a hierarchically superior status to the Constitution itself, changes have been made in the Military Criminal Code and the law on detention of mental patients. In Ireland, court proceedings have been simplified and civil legal aid and advice schemes set up ...

In France, the law relating to the secrecy of telephone communications had to be altered, while in Italy a new Code of Criminal Procedure was enacted to change the law concerning regulation of detention on remand ... ${ }^{54}$

Great Britain is the member of the Council of Europe who has been most frequently before the European Court of Human Rights. ${ }^{55}$ For a number of years the United Kingdom, where the Queen in Parliament is sovereign and where there is no written constitution, did not include the European Convention on Human Rights in its domestic law. Now, however, Parliament has enacted the Convention on Human Rights as part of British domestic law thereby making human rights litigation and law reform campaigns possible in England.

This gradual expansion and acceptance of a European regime of rights of course, was influenced by the Second World War, the Holocaust, and the Cold War. If one compares the legal, political and cultural circumstances in Europe today with those in 1935, 1945 and 1965 one should notice remarkable changes influenced by the legal developments just described.

54. Andrew Drzemczewski \& Jens Meyer-Ladewig, Principle Characteristics of the New ECHR Control Mechanism, As Established by Protocol No. 11, Signed on 11 May 1994: A Single European Court of Human Rights is to Replace the Existing and Commission and Court in Strasbourg, 15 HUM. RTS. L. J. 81, 82-83 (1994).

55. MALONE, supra note 52, at 58 (explaining that unlike most countries in Europe the United Kingdom has no constitution or domestic guarantee of individual rights, therefore individuals are forced to use this court in protecting their individual rights). 


\section{THE RULE OF LAW}

The English speaking countries of the world are renowned citadels of the rule of law. Historically, a State monopoly for the use of violence is central to the rule of law. If the State cannot provide security for its citizens against private violence then it looses legitimacy. From the time of the conquest, English kings put a strong emphasis on the suppression and control of private violence and we in America have followed their example. In the English speaking countries, however, the rule of law has a long standing association with the protection of civil liberties. An interesting question is why the protection of civil liberties should be associated historically with the advance of the rule of law.

A possible answer is that in our understanding the rule of law governs those in authority as well as members of the public. Under the rule of law citizens should be protected by law against their government as well as against private violence. The courts are the traditional instrument in the English speaking countries for securing that protection.

The courts have another important role in maintaining the rule of law. Instead of fighting in the streets, instead of resorting to private violence disputants are encouraged to take their cases to court and abide by the result. In Somersett $v$. Stewart, ${ }^{56}$ which ended slavery in England, Granville Sharp, the London radical, served the writ of habeas corpus issued by Lord Mansfield on Captain Knowles who was holding the slave James Somersett on his ship in the Thames. ${ }^{57}$ Instead of raising his sails and sailing to Jamaica Captain Knowles appeared in court and made a response to the writ. ${ }^{58}$ I describe Captain Knowles as the law abiding ship captain.

Because people bring their disputes to court and abide by the result, courts have power, are able to maintain the rule of law and can advance civil liberties. From the experience of the English speaking countries and other parts of our world we can develop some suggestions which are not particularly original for advancing the world rule of law.

\section{A. The Control of Private Violence}

The advance of the rule of law within a particular country depends on providing security, on effectively controlling private violence. On the world stage the United Nations, the Security Council or some

57. See HEWARD, supra note 14 , at 144.

58. Id. 
similar institution must have the authority to authorize the international use of violence by one country against another. ${ }^{59}$ International violence without authorization should become illegal. ${ }^{60}$ International law is moving in that direction, but has not yet established central control of international violence.

\section{B. The Role of Courts}

Historically, courts have two important roles in maintaining the rule of law: (1) protecting civil liberties by subjecting government officials to the rule of law, and (2) contributing to the control of private violence by encouraging disputants to bring their disputes to court and abide by the result. The two roles are not unconnected.

In any particular country, encouraging the citizens to bring their disputes to court rather than fighting in the streets would be a positive contribution to the rule of law and would lay a foundation for courts to assist in the protection and advance of civil liberties.

Internationally, we are making some progress in the establishment of courts to which countries and their citizens can bring their disputes. The progress in particular regions of the world is more remarkable. Most remarkable is the growing power of the courts of the European Community. In Europe, the European Covenant on Human Rights, the work of the European Court of Human Rights, and the gradual inclusion of the covenant in the domestic law of the European states is dramatic progress, although progress that was made gradually.

\section{Gradual Progress Can Be Made Towards Establishing the International Rule of Law in Several Ways.}

Using European developments as a model, regional courts can be

59. In the current state of affairs the ability of members of an international organization to set aside their personal bias is questionable. For example, when the United States brought a motion before the U.N. Security Council to enforce the cease fire agreed to by Iraq in 1991, several nations vetoed it. It later came to light that these nations (France, Russia, and China) were receiving kickbacks from the oil for food program, and as such had incentive not to invade Iraq and remove Saddam Hussein from power.

60. There have been several attempts throughout history to outlaw war. See, e.g., Treaty Providing for Renunciation of War as an Instrument of National Policy, Aug. 28, 1929, 46 Stat. 2343, 94 L.N.T.S. 57; see U.N. CHARTER art. 1 para. 1, which provides in pertinent part: ("To maintain international peace and security, and to that end: to take effective collective measures for the prevention and removal of threats to the peace, and for the suppression of acts of aggression or other breaches of the peace, and to bring about by peaceful means, and in conformity with the principles of justice and international law, adjustment or settlement of international disputes or situations which might lead to a breach of the peace."). 
established. Within countries international investment and commercial activity will be advanced by growing acceptance of the rule of law and by the availability of courts which will resolve commercial disputes. ${ }^{61}$ International commercial treaties, arbitration and the availability of courts for dispute settlement gradually will accustom disputants to taking their disputes to court and abiding by the results. ${ }^{62}$

\section{There Is a Close Connection Between the Function of Courts In} Protecting the Rights of Citizens Against Their Governments and the Establishment of The Rule of Law.

The rule of law, as we understand it, requires that government officials be governed by law. When courts enforce that, the confidence of citizens in the courts and their willingness to bring their disputes to court should increase, thereby reducing at least the major incidents of private violence. Surely, the series of propositions I just offered can be transformed into hypotheses, which can be studied using the tools of social science. ${ }^{63}$

\section{LEGITIMACY, RIGHTS AND PRIMARY SOCIAL GOODS}

Legitimacy power, according to Duncan Kennedy, is enhanced when a judge decides an important pace-making case, a significant step in law reform, while offering good legal arguments in his opinion in support of the decision. ${ }^{64}$ Changes or developments in law or legal institutions can enhance the legitimacy power of the courts or society or they can produce legitimacy costs. ${ }^{65}$ Ultimately, Brown v. Board of Education ${ }^{66}$ enhanced the legitimacy power and the historical reputation of the Warren Court. The decision itself is one of the great historic achievements of our court system. It has a quality, which I describe as ultimate legitimacy. Nevertheless, in its immediate aftermath and over the years, the Brown decision produced legitimacy costs. ${ }^{67}$

61. For example (1) The London Court of International Arbitration; (2) European Court of Arbitration; (3) The Permanent Court of Arbitration.

62. See DonNelly, supra note 7, at 62.

63. See Donald T. Campbell and Julian C. Stanley, Experimental and QuasiEXPERIMENTAL DESIGNS FOR RESEARCH (Houghton Mifflin 1963). Quasi-experimentation constitutes a class of empirical studies that lack two of the usual features of experimentation: (1) the lack of full control, and (2) absence of randomization. Id.

64. Kennedy, supra note 21 , at 527-28.

65. See DONNELLY, supra note 7 , at 10.

66. See Brown, 347 U.S. 483.

67. See DONNELly, supra note 7, at 150 (a decision is supported by ultimate legitimacy if it is by reasons that have the possibility of being acceptable to all persons at all times 
Legitimacy power can accumulate slowly case by case during a sequence of law reform or over the history of an institution. A judge who renders a series of important decisions supported by good legal argument grows in legitimacy power. ${ }^{68}$ As an example, consider Judge Benjamin Nathan Cardozo and such decisions as MacPherson v. Buick Motor Co. ${ }^{69}$ and Palsgraf v. Long Island Railroad. ${ }^{70}$ Consider as a second example the growing legitimacy power of the institutions of the European Union.

Various authors offer differing theories of legitimacy. In my book, A Personalist Jurisprudence, The Next Step, I compare, for example, the differing views on legitimacy of Cass Sunstein ${ }^{71}$ and Ronald Dworkin. ${ }^{72}$ One can derive insights regarding legitimacy from the now ancient quarrel between H.L.A. Hart ${ }^{73}$ and Lon Fuller. ${ }^{74}$ Hart understood law as a system of rules accepted by the people and spent considerable time explaining what he meant by acceptance. Lon Fuller was more concerned with the circumstances and conditions which would enhance the acceptability of law and make it more likely that it would be acceptable. An inquiry using the tools of social science into the qualities which make law or changes in law more likely to be acceptable would seem to advance our understanding of how to promote the rule of law and the advance of human rights.

Dworkin contends that the legitimacy, and I would say the acceptability of law, is grounded "not in the hard terrain of contracts or duties of justice or obligations of fair play that might hold among strangers, where philosophers have hoped to find it, but in the more

because they are based on respect and concern for each person.) N.B. all persons need not accept the reasoning the mere possibility of acceptance by all suffices.

68. Kennedy, supra note 21, at 527-28.

69. 217 N.Y. 382 (N.Y. 1916).

70. 248 N.Y. 339 (N.Y. 1928).

71. See Donnelly, supra note 7, at 39 (discussing CASS R. Sunstein, Legal REASONING AND PolitiCAL Conflict 53 (Oxford Univ.Press 1996)). Sunstein argues: "Legitimacy stems not simply from principled consistency on the part of the adjudicators, but from a justifiable exercise of authority, which requires a theory of just institutions. That theory should in turn be founded in democratic considerations suitably constrained by an account of what interests should be immunized from democratic intrusions. Legitimacy is an outcome of well-functioning democratic processes, not of a system of distinction-making undertaken by judges. Even if done exceptionally well, distinction-making by principled judges is too court-centered as a source of legitimacy." Id.

72. See DwORKIN, supra note 11.

73. H.L.A. Hart, Positivism and the Separation of Laws and Morals, 71 HARV. L. REV. 593 (1958).

74. Lon Fuller, Positivism and Fidelity to Law-A Reply to Professor Hart, 71 HARV. L. REV. 630 (1958). 
fertile ground of fraternity, community and their attendant obligations." 75 Dworkin argues that "[p]olitical association, like family and friendship and other forms of association more local and intimate is itself pregnant of obligation." 76 Dworkin's understanding of legitimacy then resembles his theory of political friendship.

Political friendship, as a grounding for the legitimacy and acceptability of law and society's institutions, would seem to present both problems and opportunities for furthering the global rule of law. A new institution, an international court, for example, does not fit easily into the existing pattern of political friendships and interactions. However, as human interactions slowly grow around that new institution it will become more acceptable. Witness the growth in authority and legitimacy of the European courts. Those activities may be the normal interactions of people who move from country to country. In our world today commercial activities will be an important element of those interactions which lead to political friendships.

Personalist theory, as I describe it in my book, A Personalist Jurisprudence, The Next Step, offers a foundation for political friendship in the perception that persons are interrelated, that we are more fully persons when in relation with other persons. ${ }^{77}$ At the foundation of personalist theory is the perception of a necessary interrelationship between persons and a commitment to afford each person deep respect and concern. ${ }^{78}$ That perception and that commitment provide a basis for personalist acceptance of Dworkin's theory of political friendship. ${ }^{79}$ Political friendship as understood in view of that perception and commitment then leads to a theory of rights, obligations and legitimacy.

In personalist theory, one has an obligation to cooperate in building and maintaining the reasonable institutions of the society in which he finds himself, that is because one has a duty of respect and concern for the persons with whom one inevitably is engaged in interaction.

75. DWORKIN, supra note 11, at 206.

76. Id.

77. The personalist ideal, "is a universal community of persons in which each cares for all other" because "the self-realization of any individual is only fully achieved if he is positively motivated towards every other person with whom he is in relation." See DONNElly, supra note 7, at 99-100 (quoting JoHn MACMURRAY, PERSONS IN RELATION 159 (Faber London 1970)).

78. See DoNNELLY, supra note 7 , at 88 .

79. Id. 
One interacts with others through language, through the circumstances of daily living, through all the ways in which one exists in modern society. One understands himself as a person through that interaction with other persons whom one perceives in the course of action as persons. ${ }^{80}$

The theory of rights like the theory of political obligations arises from that perception of persons acting together in society and hence growing more fully as persons. Each person under personalist theory has a right to participate in the common action of society and a right to the means necessary for that participation. ${ }^{81}$

The means necessary for participation in the common action of society could be described as the primary social goods. The primary social goods are those necessary or important both generally and in any particular society for participation in the common action of that society. ${ }^{82}$ The concept, primary social goods, is borrowed from John Rawls' $A$ Theory of Justice and slightly transformed. Rawls would define the primary social goods as those necessary to pursuing any rational plan in life. In Rawls' theory the principles of justice derived in his Original Position are those which will assure all parties the best chance of maximizing their share of the primary social goods on lifting of the veil of ignorance and the best chance of minimizing disastrous losses of the primary social goods.

In personalist theory without the crutch or aid of the Original Position $^{83}$ and the Veil of Ignorance, ${ }^{84}$ the primary social goods nevertheless are very helpful in constructing a theory of rights. Basic

80. See DONNELLY, supra note 7 , at 241 .

81. Id. at 296.

82. See id. at 101.

83. See RAWLS, supra note 9 , at 118 . The original position is a model to help man determine what is just or unjust. In this model there are numerous pieces of a game that make decisions that affect society as a whole. While making these decisions it is assumed that the parties will make decisions that tend to maximize the potential good they can experience, while at the same time minimize the potential harm they can suffer. After the pieces of the game make their decisions the ultimate decision maker, i.e., the player of the game, makes the ultimate decision if a proposed rule of law is just.

84. Somehow we must "nullify the effects of specific contingencies, of the pieces in the original position that put men at odds and tempt them to exploit social and natural circumstances to their own advantages." In order to accomplish this goal Rawls assumes the pieces are situated under a veil of ignorance. While under the veil the pieces do not know how the various alternatives will affect their own particular case and they are obliged to evaluate the principles solely on the basis of general consideration. Furthermore, while under the veil the pieces do not know inter alia: (1) their place in society; (2) class; (3) social status; (4) fortune; (5) intelligence; or (6) strength. Id. at 136-37. 
rights are those designed to protect the primary social goods. A number of these rights would be found in our United States Constitution and some in the rest of our law. ${ }^{85}$ In A Personalist Jurisprudence, The Next Step, I argue:

Respect, then, for each person's right to participate in the intersubjectivity or political friendship of the common action, the life of the community becomes the basis for the primary rights. Primary rights are those which would protect against deprivation of the personal, economic, and political goods necessary to basic participation in any society's and in this particularly society's common action. ${ }^{86}$

In personalist theory, the understanding of legitimacy is grounded in political friendship, respect and concern for each person, persons interacting in the common action and their right to the primary social goods necessary to continue that participation. ${ }^{87}$ Legitimacy in personalist thought then shares a common grounding with the theories of rights and obligations.

In A Personalist Jurisprudence, The Next Step, I argue that "[a] society is legitimate to the extent that it strives to advance and protect everyone's and each one's share of the primary social goods." 88 Particular institutions and activities of society are legitimate insofar as they share or participate in society's mission of enhancing the common action, affording respect and concern for each person and protecting and improving each person's share of the primary social goods, that is, each person's opportunity to participate in the common action of society. ${ }^{89}$

For example, the judicial system is legitimate because by reasonable settlement of disputes it advances and maintains the rule of law. ${ }^{90}$ Members of society are encouraged by the possibility of reasonable settlement of disputes to bring their cases to court rather than

85. See, e.g., U.S. CONST. amends. I, V, VI, VIII, XIV (Freedom of Speech and Press (Amendment 1); due process of law (Amendments 5 and 14); trial by jury and confrontation of witnesses (Amendment 6); and prohibitions against cruel and unusual punishment (Amendment 8).

86. See Donnelly, supra note 7, at 107-08 (quoting Samuel J. M. Donnelly, Towards a Personalist Jurisprudence: Basic Insights and Concepts, 28 LoY. L.A. L. REV. 547, 589 (1995)).

87. See DoNNELLY, supra note 7, at 75.

88. See id. at 241.

89. Id. at $239-46$.

90. Id. at 240 . 
fight out the disputes in the streets. If they can obtain fair results in challenges through judicial proceedings against government officials that will advance the rule of law and reduce incentives to violence. Maintaining the rule of law in this manner, a principal mission of the courts, advances everyone's share of the primary social goods and opportunity to participate in society.

I have just offered then a set of interrelated concepts and perhaps theories, understandings of rights, obligations, legitimacy and the primary social goods all grounded in respect and concern for each individual and each person's interaction with others in the common action of society.

A question then proposed is whether those concepts are helpful in studying or practically advancing human rights and the rule of law both internationally and in particular countries. For example, if one is attempting to establish a stable and legitimate government in a "disorderly" corner of the world, a series of concrete steps would be sponsored by the theories just advanced:

First, in order to maintain the rule of law, the government must substantially suppress private violence. By providing that security to society most citizens share of the primary social goods will be enhanced thereby advancing the legitimacy of the government.

Second, at a reasonably early stage there should be a court system, which will entertain private actions. Members of society hopefully will bring their disputes to court rather than fight in the streets. By this means, private violence will be reduced further, primary social goods will be protected and the legitimacy of society advanced.

Third, government members should be subject to the rule of law thereby advancing the protection of rights, the rule of law, and everyone's share of the primary social goods. For those reasons, the new government will be perceived more clearly as legitimate.

Fourth, basic human rights or some of them should be protected by the government producing similar results.

Now, adapt that set of steps to the establishment of a regional union, for example, the European Union. The victory of the Allies during World War II and the eventual demise of the Cold War established internationally within Europe a reduction and control of violence followed by treaties codifying that elimination of violence. ${ }^{91}$

91. See, e.g., North Atlantic Treaty, Apr. 4, 1949, 34 U.N.T.S. 243; Treaty of Friendship, Cooperation, and Mutual Assistance Alb.-Bulg.-Hung.-F.R.G.-Rom.-U.S.S.R.Czech Rep., May 14, 1955, 219 U.N.T.S. 3. 
The European Covenant on Human Rights ${ }^{92}$ and a court designed to enforce that covenant ${ }^{93}$ were established. The Court of the European Communities $^{94}$ as well as the Court of Human Rights ${ }^{95}$ provided forums for the settlement of disputes. We have witnessed a gradual advance in the stability of Europe and the legitimacy of the European Union. ${ }^{96}$

What I am offering, of course, are some interrelated concepts which may be helpful in understanding the advance of the rule of law and the related promotion of human rights. Social scientists must tell whether they can make use of these concepts and practitioners will discover whether they are useful as a basis for refining their tools. Ultimately the test of this pudding will be in the eating.

Some of the obstacles to the further development of the international rule of law and the advance of human rights perhaps may be captured in some further but related concepts. In the next part, I want to discuss the problem of horizons and the various points of view from which rights are perceived.

\section{THE LANGUAGE AND USES OF RightS: RightS AS TOOLS IN THE PROCESS OF SOCIAL CHANGE}

A great obstacle to the advance of human rights and to the establishment in the international sphere of the rule of law is the phenomenon I refer to as horizons. This is a familiar phenomenon. In international human rights discourse, one regularly encounters the discussion of whether economic rights are more important than civil

92. See generally European Convention, 213 U.N.T.S. 221.

93. Id. at art. 19 (creating the European Court of Human Rights). $87 / 04$.

94. See Treaty Establishing A Constitution for Europe, Aug. 6, 004, art. I-29 CIG

95. European Convention, 213 U.N.T.S. 221, at art. 19.

96. See Statute of the Council of Europe, May 5, 1949, 87 U.N.T.S. 103 (a decision by the Congress of the European Movement in May 1948 created the Council of Europe); see also Andrea Schultz, The 1980 Hague Child Abduction Convention and the European Convention on Human Rights, 12 TransNat'L L. \& CONTEMP. ProB. 355, 357 (2002) (within the framework of the Council of Europe certain organizations were created having authority to control the application of the Statute viz. The European Commission of Human rights in 1954 and The European Court' of Human Rights in 1959 ("These Council of Europe organs are not to be confused with the European Commission, i.e., the executive of the European Union and with the European Court of Justice")). Id. at n. 8. 
liberties or vice versa. ${ }^{97}$ Not surprisingly, the priority for economic rights is favored in some developing countries with strong or dictatorial central regimes while thinkers like John Rawls, writing in democratic countries, would favor a priority for civil liberties. ${ }^{98}$ Likewise, rights considered basic and important in European and Western circles are questioned in the Middle East. ${ }^{99}$

In my book, $A$ Personalist Jurisprudence, The Next Step, I argue that every statement concerning rights is made within a horizon and from a point of view. ${ }^{100}$ I would like to begin this part of the discussion by elucidating that argument and by explaining the terms horizon and point of view.

The term "horizon" is used by philosophers such as Bernard Lonergan, ${ }^{101}$ Martin Heidegger ${ }^{102}$ and Hans Georg Gadamer ${ }^{103}$ as a metaphor to discuss "the normal human condition of having limited knowledge and understanding." Literally, horizon refers to the line at the edge of the sky and earth which marks the limits of our physical vision. We all know that there are mountains, valleys, cities and lakes beyond the circular line of the horizon and hence beyond our physical vision. A valuable aspect of the metaphor is that we also know that we can cross beyond our present physical horizons and find those cities and

97. It has been argued that Asian Countries disagree with the theory of individual human rights the West uses, instead arguing the principle need in Asia is economic development contrary to the importance the West places on civil and political rights. Moreover in Asia social and economic rights are more important and will receive a higher priority. See, e.g., Bina D'Costa, Challenges for an Independent Asian Human Rights Commission ILSA J. INT'L \& COMP. L. 615 (1998); see also RAWLS, supra note 9, at 53 (Lexical priority of principle of equal liberty or over the second property of fair distribution).

98. See Robert Burns, Law and Social Theory: Rawls and the Principles of Welfare Law, 83 NW. U. L. REV. 184, n. 35 (1988) referring to RAWLS, supra note 9, at 60-90 ("One may compare Rawl's exposition of the varying degrees of equality required in political and civil rights as opposed to social and economic rights.").

99. See, e.g., THE 9/11 COMMISSION REPORT: FINAL REPORT OF THE NATIONAL COMMISSION ON TERRORIST ATTACKS UPON THE UNITED STATES 51 (Auth. Ed.) ("Many Americans have wondered, 'Why do they hate us?' some also ask 'What can we do to stop these attacks?' Bin Laden and al Qaeda have given answers to both these questions. To the first, they say.... America is responsible for all conflicts involving Muslims. [T]o the second question ... America should abandon the Middle East, convert to Islam, and end the immorality and godlessness of its society and culture." Id.

100. See DONNELLY, supra note 7 , at 260.

101. See BERNARD J. F. LONERGAN, MEthod IN ThEOlOgY 235-36 (2d ed.) (1970).

102. See MARTIN M. HeIDEGGER, IDENTITY AND DifFERENCE 34-35 (J. Stamburgh trans. 1969).

103. See HANS-GeORg GADAMER, TRUTH AND Method 303, 306-07 (Joel Weinsheimer \& Donald G. Marshall, trans., 1975). 
mountains. I can leave this university, hop into my car and drive to Skaneateles Lake. If I do, my whole view, my physical scenery and my emotional mood, will change.

Likewise, we can cross our intellectual and cultural horizons. I can leave the law school and cross the parking lot to the Maxwell School of Citizenship where I can study economics, history or sociology, thereby changing my intellectual outlook and vision.

Horizons, both physical and intellectual, create and also confine vision. I can see to the edge of the horizon to the limits of my current knowledge and interest, but not beyond. By crossing horizons physically and intellectually, I can expand my vision. Fascinatingly, however, when I cross horizons I find myself in a new horizon which also creates and confines vision. When I leave college with a degree in economics, sociology or history and enter law school I find new vision but gradually forget and loose interest in the social sciences.

Horizons affect our understanding of rights. A philosopher and a lawyer will discuss rights differently as will persons brought up in various cultures. Representatives from the Near East, for example, regularly tell us that our Western understanding of rights does not make sense in their cultures. A familiar phenomenon, however, is that a person returning to the East from an education in Paris or Boston may turn out to be an advocate for a more western understanding of rights in his or her home country and culture. ${ }^{104}$ Sometimes what Hans-Georg Gadamer calls a fusion of horizons takes place. ${ }^{105}$

To understand statements regarding rights, I often argue, one must recognize that every rights statement is made within a horizon and from a point of view. A district attorney talking about rights, perhaps the rights of a victim, is speaking from a different point of view and perhaps with a different meaning than a defense attorney. The judge's point of view is yet different. Social scientists and some legal philosophers could talk about rights from a descriptive point of view. That very definitely is not the point of view of a law reform attorney campaigning for the establishment of new rights. ${ }^{106}$ That would not have been the point of view of Thurgood Marshall during the long campaign leading to Brown v. Board of Education. ${ }^{107}$

A law reformer such as Thurgood Marshall or Granville Sharpe

104. Such an example is the 2003 Nobel Peace Prize winner Shirin Ebadi.

105. HANS-GEORGE GADAMER, supra note 103, at 306-07.

106. See Donnelly, supra note 7, at 283-89.

107. 347 U.S. 483. 
following Somersett $v$. Stewart, ${ }^{108}$ would not perceive rights descriptively, or as entitlements, or as conclusions to be drawn within a system of law. Probably he would find Llewellyn's Holmesian understanding of rights as predictions that a court would afford a remedy only moderately helpful. ${ }^{109}$ Rather he would perceive rights as goals to be pursued and great decisions such as Somersett $v$. Stewart or Brown v. Board of Education not only as important victories but also as resources for further pursuit of the goal of complete abolishment of slavery and the slave trade or of desegregation. As Stuart Scheingold points out, the legitimacy power of a great victory becomes a resource for the next battle in the further pursuit of rights. ${ }^{110}$

Likewise, from the point of view of a judge, that is, the point of view of one concerned with action, with deciding a case, rights are not predictions of what a court will in fact do. The point of view of a judge is neither a descriptive nor a predictive point of view. According to H.L.A. Hart, a judge may perceive rights as conclusions to be drawn in a system of rules. ${ }^{111}$ Or he may perceive the rights he is about to establish as an appropriate resolution in his culture of a long standing dispute.

Both the judge and the law reform attorney should be conscious of the phenomenon of horizons. When a law reformer is addressing a judge whose horizons are narrow, he must find a way to make his arguments comprehensible within the narrow horizons of the judge. ${ }^{12}$ In the alternative, he must find ways to persuade the judge to cross beyond those narrow horizons to see and understand the problems of his client. ${ }^{113}$ Some great appellate advocates have that skill.

As Stuart Scheingold points out, rights are resources to be used in the political campaign for law reform. ${ }^{114}$ The legitimacy power of courts allows a reform campaign to rally its supporters and to attack its opponents. When arguing before a judge, a law reform attorney may use the legitimacy power of rights to hammer on the judge's narrow horizons demanding that the judge respect and pay attention to his client's rights, his client's interests and his client's standing as a

108. 98 Eng. Rep. 499.

109. See DonNELly, supra note 7, at 254 referring to Karl N. Llewellyn, A Realistic Jurisprudence-The Next Step, 30 ColuM. L. REV. 431, 462-63 (1930).

110. See SCHEINGOLD, supra note 38 , at 83-84.

111. See DonNELlY, supra note 7, at 255.

112. Id. at 283-89.

113. Id.

114. See SCHEINGOLD, supra note 38 , at $83-84$. 
person. $^{115}$

Events in the wider world may provide society and courts with the vital experiences necessary to abandon or cross old horizons. Not long before the decision in Brown v. Board of Education, ${ }^{116}$ the world was challenged by the experience of World War II and the Holocaust. In the United States, shortly before that, we had the experience of the Great Depression and after the war, Truman's desegregation of the military, the beginning of the Cold War and the Korean War. All of these experiences along with the NAACP's extensive law reform campaign would have contributed to the new necessary change of horizons that made Brown v. Board of Education possible. ${ }^{117}$ World War II, the Holocaust, and the Cold War also were experiences that changed European horizons and contributed to the new atmosphere which allowed development of the European Union and the evolutionary advance of human rights in Europe. ${ }^{118}$

A law reformer, or one concerned with the advance of the rule of law and human rights, should be conscious of the phenomenon of horizons, of the experiences which open the opportunity for expanding our horizons and should seek the tools necessary for hammering on foreign horizons. Among those tools is the legitimacy power of rights which can be used as a resource in pursuing further goals like establishing additional or more fundamental rights.

From the perspective of a conscientious judge, consciousness of the phenomenon of horizons would be significant. A judge recognizing his horizons, his limited knowledge and understanding, and desiring to decide justly or perhaps having a commitment to respect and concern for all persons should accept an additional and corollary obligation to

115. See DONNELLY, supra note 7 , at 283-89.

116. 347 U.S. 483.

117. See DONNELlY, supra note 7, at 144-45.

118. See, e.g., Barbara Crutchfield George, et al., Increasing Extraterritorial Intrusion of European Union Authority Into U.S. Business Mergers and Competition Practices: U.S. Multinational Businesses Underestimate the Strength of the European Commission from G.E.-Honeywell to Microsoft, 19 CoNN. J. INT'L L. 571, 573-74 (2004) ("When the Cold War threat, hanging over Europe for decades, was eliminated with the fall of the Berlin Wall in 1989, Europe was free to develop its centralized institutional structure. .."); see also Charles W. Smitherman III, The Future of Global Competition Governance: Lessons from the Transatlantic, 19 AM. U. INT'L L. REV. 769, 823 (2004) (citing Eric S. Hochstadt, The Brown Shoe of European Union Competition Law, 24 CARDOzo L. REV. 287, 318 (2002)) ("The creation of the European Union and the Common Market itself finds much of its foundation in rebuilding a war torn continent following the end of the Second World War and the desire for an economic unity and interdependence, especially in the post-Cold War era."). 
cross horizons and to develop methods for crossing horizons. ${ }^{119}$ Social science and social science data, despite or perhaps because of their controversial use in Brown v. Board of Education, ${ }^{120}$ are among the tools for enabling a judge to cross horizons and recognize the impact of his decisions on those in foreign horizons. A commitment to, and methods for, crossing horizons are both a means for promoting human rights and a topic for exploration by legal philosophers and social scientists. ${ }^{121}$

The process of developing and establishing rights then should be perceived and studied in relation to the problem of horizons, the possibility of crossing horizons and the means for doing that. ${ }^{122}$ Lawyers, legal philosophers and social scientists can study the problems from various points of view. Accordingly, lawyers and legal philosophers should be conscious of horizons and should seek to create tools for crossing them from the point of view of the judge and the point of view of an advocate for the disadvantaged. ${ }^{123}$

The advance of rights, perhaps with the help of horizon crossing techniques, is related in turn to the advance of the rule of law and to the legitimacy of new governmental arrangements perhaps regional unions. To the extent that rights are secured and recognized within a horizon, people are encouraged to take their disputes to court, to settle them peacefully, to sue government officials or entities who are subject to the rule of law rather than starting revolutions or campaigns of terrorism. A law reform campaign seeking the establishment of new rights is a substitute for revolution. That campaign can take place within a particular country, within a regional organization, such as the newly developed structures in Europe, or hopefully on a global scale in the future. The availability and regular use of the process of law reform to establish rights should contribute to the legitimacy and stability of governments and regional organizations. The regular use of law reform campaigns should contribute to strengthening and expanding the rule of law.

For that purpose it helps to understand rights not simply as rules or entitlements but as tools, perhaps as language tools for the accomplishment of human purposes. In my book, $A$ Personalist Jurisprudence, The Next Step, I describe a number of different uses of

119. See DoNNELLY, supra note 7 , at 86-87.

120. 347 U.S. 483.

121. See DoNNELLY, supra note 7, at 294.

122. Id.

123. Id. at 260 . 
the language of rights. Rights may be perceived as remedies or predictions that a court may afford a remedy, as conclusions drawn within a system of rules by way of a judicial decision, by arguments for that decision, or criticisms of it, as reasons for that decision, as particularly powerful reasons which will trump competing reasons, as goals to be pursued, or as resources for pursuing those goals. ${ }^{124}$

\section{NATURAL LAW}

In the first volume of his A History of the English-Speaking Peoples, ${ }^{125}$ Winston Churchill discussing the Magna Carta explained:

If the thirteenth century magnates understood little and cared less for popular liberties or Parliamentary democracy, they had all the same laid hold of a principle which was to be of prime importance for the future development of English society and English institutions. Throughout the document it is implied that here is a law which is above the King and which even he must not break. The reaffirmation of a supreme law and its expression in a general charter is the great work of Magna Carta; and this alone justifies the respect in which men have held it. The reign of Henry II, according to the most respected authorities, initiates the rule of law. But the work as yet was incomplete: the Crown was still above the law; the legal system which Henry had created could become, as John showed, an instrument of oppression.

Now for the first time the King himself is bound by the law. The root principle was destined to survive across the generations and rise paramount long after the feudal background of 1215 had faded in the past. The Charter became in the process of time an enduring witness that the power of the Crown was not absolute. ${ }^{126}$

In this passage Winston Churchill sketches some major steps in the establishment of the rule of law. Most importantly, the institutionalization of a higher law, accomplished through the Magna

124. See DonNelly, supra note 7 , at 255-59.

125. Winston S. Churchill, A History of the English-Speaking Peoples: The BIRTH OF BRITAIN 256-57 (Dodd, Mead \& Co. 1956).

126. $I d$. 
Carta, subjects the king to the rule of law. When the government is subject to the rule of law, we have a strong foundation for the development of civil liberties and the advance of human rights. The institutionalization of higher law for this purpose is in the main stream of the natural law tradition.

Natural law in its many incarnations over the ages has served as a vast storehouse of resources for the advance of the rule of law. ${ }^{127}$ The Romans borrowed the notion of natural law from Greek philosophers, particularly the Stoics, and used it to mold the law necessary to govern their vast empire. ${ }^{128}$ As their empire grew, the Romans confronted a problem not entirely dissimilar to the current world situation. For the sake of commerce, good order and justice the Romans required an international law, a law of nations, a jus gentium, as they described it. That jus gentium should not be the law of a particular state including their own. Rather they drew on the themes common to many laws to create a higher law. The labors of the great Roman jurists, in developing the jus gentium and the jus naturalis, were ultimately codified by the Emperor Justinian in his famous Codex which has served to advance the rule of law over the ages. ${ }^{129}$

Medieval natural law, ${ }^{130}$ as Churchill explained, influenced the Magna Carta distinctively, jump-starting the history of English civil liberties. The tradition, which began with the Magna Carta, supported by the natural rights philosophy of John Locke, provided a foundation for the overthrow of the Stuart kings and their pretensions to absolutism. ${ }^{131}$ About the same time, the great seventeenth century

127. See, e.g., Alessander PASSERIN D'EnTREVES, NATURAL LAW: An INTROdUCtion TO Legal PhILOSOPHY (Hutchinson Univ. Library 1951); ThOMAS AQUINAS, SumMA Theologica (Fathers of the English Dominican Province Trans., Benziger Bros. 1947); Marcus Tullius Cicero, De Republic; Hugo Grotius, LaW of War and Peace (1625); Samuel Pufendorf, De Jure Naturae et Gentium (1682); Jean JacQues Burlamagui, PRINCIPLES DU DROIT NATUREL (1747).

128. See D'ENTREVES, supra note 127.

129. Judge Albert Rosenblatt of the New York Court of Appeals states: "At its height, the Roman Empire ruled over much of the known world. It is a tribute to the Roman sense of pragmatism that they were able, with almost scientific ability, to craft laws of such universality as to seem part of the natural order of things. As a model rule of law for all Western society, culminating in the Justinian Code of the sixth century, the articulation of law by Rome, must be counted as a giant stride in the history of law on this planet." See Albert M. Rosenblatt, The Fifty-Fifth Annual Cardozo Memorial Lecture: The Laws Evolution: Long Night's Journey Into Day, 24 CARDOZO L. REV. 2119, 2133-34 (2003).

130. See, e.g., Aquinas, supra note 127, at 505-06.

131. Cf. Edward S. Corwin, Establishment of Judicial Review, 9 Мich. L. REV. 10, 104 (1910). 
natural lawyers, Grotius ${ }^{132}$ and Pufendorf, ${ }^{133}$ whom Dr. Schwartz admires greatly, were using the resources of the natural law tradition to form the foundations of modern international law, ${ }^{134}$ a distinct advance in establishing a world rule of law.

Thomas Jefferson, in the next century, drew on John Locke's natural rights theory to lay, in the Declaration of Independence, the foundation for development of the American tradition of human and civil rights. ${ }^{135}$ In turn, the American tradition made perhaps the most significant contribution to the modern worldwide advance of human rights.

The notion of a higher law, whatever its foundation, is the essential contribution of the natural law tradition to the advance of the rule of law and the promotion of human rights. ${ }^{136}$ In the absence of positive law, a jus gentium or modern international law can be developed on the foundation of that higher law. Under the authority of that higher law, kings and governments can be subjected to the rule of law and their

132. See GrotiUs, supra note 127 , at $38-39$.

133. See PUFENDORF, supra note 127.

134. See Shana Wallace, Beyond Imminence: Evolving International Law and Battered Women's Right to Self-Defense, 71 CHI. L. REV. 1749 (2004). Prior to the adoption of the United Nations Charter, the concept of jus ad bellum - or a just use of force or recourse to war-had developed over several thousand years. This theory was the product of early Greek philosophers such as Aquinas and secular theorist of just war such as Grotius developed this concept through analogy and reference to an individual's right to selfdefense. Id.

135. Locke stated that "men formed society primarily to secure their natural rights of life, liberty, and property." See EDWARD J. EBERLE, DIGNITY AND LIBERTY: Constitutional Visions IN GERmanY AND THE United STATES 42 (2002). Jefferson's first draft of the Declaration of Independence copied Locke's trinity verbatim. See MASTERPIECES OF WORLD PHILOSOPHY 269 (Frank N. Magill ed., Harper Collins 1990). However, the Declaration final draft read, "We hold these truths to be self-evident, that all men are created equal; that they are endowed by their Creator with certain unalienable rights; that among these are life, liberty, and the pursuit of happiness; that, to secure these rights, governments are instituted among men..." See THE DECLARATION OF INDEPENDENCE para. 2 (1776).

136. Cicero argued: "True law is right reason in agreement with Nature; it is of universal application, unchanging and everlasting; it summons to duty by its commands and averts from wrongdoing by its prohibitions. And it does not lay it commands or prohibitions upon good men in vain, though, neither have any effect on the wicked. It is a sin to try to alter this law, nor is it allowable to attempt to repeal any part of it, and it is impossible to abolish it entirely. We cannot be freed from its obligations by Senate or People, and need not look outside ourselves for an expounder or interpreter of it. And there will not be different laws at Rome and at Athens, or different laws now and in the future, but one eternal and unchangeable law will be valid for all nations and for all times, and there will be one master and one ruler, that is, God, over us all, for He is the author of this law, its promulgator, and its enforcing judge." See CiCERO, THE REPUBliC THE LAWs 68-69 (Niall Rudd trans., 1998). 
citizens' civil and human rights can be protected against those ruling powers. That protection of citizens and control of rulers, however, as we examine our history, has been promoted best by the institutionalization of that higher law. To mention some instances, that institutionalization of higher law is represented by the Magna Carta, ${ }^{137}$ by the British Bill of Rights of $1688,{ }^{138}$ by the American Constitution and its own Bill of Rights ${ }^{139}$ as administered by our Supreme Court, by the United Nations Declaration of Human Rights, ${ }^{140}$ by the Covenants on Civil and Political Rights, ${ }^{141}$ and on Economic, Social and Cultural Rights, ${ }^{142}$ by the European Union, ${ }^{143}$ by the European Convention on Human Rights, ${ }^{144}$ by the European Court of Human Rights. ${ }^{145}$

From that history clues can be derived for advancing the rule of law and the protection of human rights in our modern world. Our developing international law could serve as the higher law which could subject otherwise unrestrained rulers to the rule of law and respect for the human rights of their citizens. ${ }^{146}$ There is some indication in the flow of current events that this process is beginning. ${ }^{147}$ It is necessary, however, to institutionalize that process probably through the United Nations and regional organizations modeled on the European Union.

The set of related concepts offered in this paper and discussed above in Parts II through V may be helpful to understanding the relation between a higher law perhaps derived from natural law, the institutions which apply that higher law and the evolutionary development of the rule of law and the related advance of human rights. Those concepts include the rule of law; the language and uses of rights; primary social

137. See generally MAGNA CARTA (1215).

138. See generally BRITISH BILL OF RIGHTS (1689).

139. See generally U.S. CONST.

140. See Universal Declaration, supra note 47.

141. See ICCPR, 999 U.N.T.S. 171.

142. See International Covenant on Economic, Social, and Cultural Rights, opened for signature Dec. 19, 1966, 993 U.N.T.S. 3.

143. See Treaty on European Union, Feb. 7, 1992, 31 I.L.M. 253.

144. See European Convention 213 U.N.T.S. 221.

145. This court was created in Article 19 of the European Convention on Human Rights. See id. art. 19.

146. See David L. Nersessian, The Contours of Genocidal Intent: Troubling Jurisprudence from the International Criminal Tribunals, 37 TEX. INT'L L. J. 231, 233 (2002). "Beginning with the Holocaust, the international community began to treat genocide as criminal under international law, rather than excusing it as an unfortunate (but necessary) incident to state sovereignty." Id.

147. Id. at 234. This process began with the Nuremberg and Tokyo trials following the Second World War. More currently this is demonstrated by war crimes tribunals for Rwanda and the former Yugoslavia. Id. at 235. 
goods; legitimacy; horizons; crossing horizons; point of view analysis; and the use of rights as tools in the process of social change.

As just explained, the institutionalization of natural law or higher law can be used to subject rulers to the rule of law. That advance of the rule of law in turn creates respect for the rights of citizens. While a government controlled by an uncommanded sovereign may exercise legitimacy power, it will also suffer legitimacy costs. ${ }^{148}$ When the government is subject to the rule of law and respects the rights of citizens, those legitimacy costs are reduced. There is a desirable relation then between legitimacy, the rule of law, and respect for rights. Institutionalization of a higher law will advance the rule of law, respect for rights and, ultimately, legitimacy.

To be successful, however, an institutionalization of a higher law must be perceived as legitimate or must acquire legitimacy. This new regime of rules, as H.L.A. Hart points out, must be accepted by the people $^{149}$ - that is the challenge that confronts a new regional international organization, a new international court, or new efforts by the United Nations or world powers to enforce the rule of law in defiant Third World countries. The successful exercise of that international power to advance the rule of both law and human rights will enhance the legitimacy power and acceptance of the new organization. Initially and throughout its development, the new international organization will confront the problem of horizons. Successful horizon crossing techniques will contribute to its success.

From the earlier discussions, however, a number of other suggestions can be derived for enhancing the legitimacy and acceptability of a new international organization or a new exercise of its power. The world powers seeking perhaps through pressure or invasion to subject rulers of particular countries to the world rule of law should themselves be subject to the rule of law. A powerful country, France, Britain, or the United States will exercise greater legitimacy power if its enforcement activities are conducted through or are authorized by the United Nations or by a regional union, for example the European Union. The development of additional regional unions would be desirable. The exercise of power in the international realm, without the cloak of legitimacy, will suffer legitimacy costs and hypothetically will be more difficult and less enduring. Repeated successful enforcement of the rule of law, with legitimate authorization, in contrast, should enhance the 
world rule of law and its legitimacy power-that in turn, by subjecting rulers to the rule of law should advance human and civil rights.

Rights themselves, as they become more widely accepted, become tools in the campaign to expand rights but also to advance the rule of law. Rights may be used in this campaign simply as a particularly effective form of rhetoric. ${ }^{150}$ They can be used and are currently used in third world countries, and the United States, to hammer on foreign horizons, calling attention to oppression and persons who are oppressed. If forums, particularly but not exclusively courts, are available for asserting rights, then rights litigation will be more effective. Rights litigation then will become an important tool for gradual advancement of the rule of law and human and civil liberties. Such courts could be world courts but perhaps more usefully and effectively regional courts or even courts within particular countries. The incorporation of the European Covenant on Human Rights into the domestic law of particular European countries was a positive advance which should allow more effective law reform litigation.

The United Nations, world powers, international or regional courts all should be conscious of the problem of horizons when seeking to advance or enforce human rights and the rule of law. Horizons are expanding gradually, for example, by repeated, sensitive and successful rights litigation. Gradual development of rights and the rule of law accompanied by repeated understanding and crossing of horizons will support the legitimacy of the rule of law and the new regime of rights. There is a linkage between the rule of law, the advance of rights, the use of rights to hammer on foreign horizons, the understanding of rights within those foreign horizons, the crossing of horizons, the use of rights in the process of social change and legitimacy. The rule of law provides legitimacy for rights litigation and reform. In turn, rights litigation provides legitimacy for the rule of law. That legitimacy is enhanced, and legitimacy costs are reduced if courts and others enforcing rights and the rule of law understand horizons and are committed to crossing horizons.

Legitimacy, of course, is linked also to protection of the primary social goods, those goods necessary to participation in any society or this society. The importance of assuring security and economic wellbeing to legitimacy is clear from recent experience. The great rights are those which protect each person's share of the primary social goods, each person's life, liberty and pursuit of happiness. Advance of the

150. See SCHEINGOLD, supra note 38 , at $83-84$. 
great rights also advances the rule of law and legitimacy, the acceptability and the conditions for acceptance of the regime of law.

The interdependence of these concepts, legitimacy, rights, primary social goods, the rule of law, horizons and so on, could be described as an aspect of the functioning of natural law. From experience, including the experience of lawyers, judges and rights litigators, they are also vital concepts and tools in the institutionalization of natural law, a higher law, the rule of law. I submit that this process can be studied from the perspective of lawyers and legal philosophers and the perspective of social scientists. What should be studied is the use of tools of law and government in the process of social change, the advance of human liberties and the rule of law. We are accumulating examples both within countries and in the international arena of that process of social change.

St. Paul once described what has come to be called the natural law as written in the hearts of human persons. ${ }^{151}$ As a scripture scholar Paul was drawing on a thousand years of learning in the tradition descended from Abraham, which many of us hold in common. A reasonable interpretation of that could be put as follows.

In the course of human interaction and experience we gradually come to understand our fellow human beings as persons who share human feelings, desires, sufferings, and moral struggles. ${ }^{152}$ Out of that understanding, grow respect and concern for others, for many others. That respect and concern can be contemplated philosophically, be generalized, be transformed into individual and community commitments, be institutionalized into the rule of law, great ideals, respect for rights, the importance of courts and of rights litigation and reform. It is a gradual process, a process of continual development of human experience, influenced by vital and sometimes traumatic experience, by World Wars, by the abolition of slavery, by the Holocaust, by the successful establishment of regimes of rights such as the European Union. An important part of natural law as so understood is the process of social change and the role of human experience and ideals in that process of social change.

Natural law then is not a set of propositions or even ideals

151. Romans 2:14-16. ("Indeed, when Gentiles, who do not have the law, do by nature things required by the law, they are a law for themselves, even though they do not have the law, since they show that the requirements of the law are written on their hearts, their consciences also bearing witness, and their thoughts now accusing, now even defending them ... This will take place on the day when God will judge men's secrets through Jesus Christ, as my gospel declares.") Id.

152. See DONNELLY, supra note 7, at 233-38. 
important as they are to natural law but a process of human experience by which our regard for our fellow human beings grows, is generalized into ideals and commitments, is institutionalized and regularly changed, as by crossing horizons and gathering the experience of life, our understanding and regard for our fellow human persons deepens and broadens. Honoring Dr. Richard Schwartz's interest in natural law and his great work in law and social science, I submit that this process particularly as it is represented by institutionalized social change can be studied by lawyers, legal philosophers and social scientists.

\section{CONCLUSION}

A central theme of this paper is that a desirable relation exists between legitimacy, the rule of law and respect for rights. I argue that there is a reciprocal relation between the rule of law and respect for rights. To the extent that a government is subject to the rule of law, the human and civil rights of its citizens are advanced. In turn, as citizens with confidence bring disputes concerning violation of their rights to the courts, rather than seeking remedies in the streets, the rule of law is enhanced. Both respect for rights and the rule of law are likely to make governments more acceptable to their citizens and hence more legitimate. Effective establishment of the rule of law and respect for rights will enhance everyone's share of the primary social goods and consequent ability to participate in society. A basic requirement of legitimacy is that a government ought to protect and enhance everyone's basic share of the primary social goods. Understanding and crossing horizons allows courts, rulers and law reform litigators to understand rights and basic interests, i.e., primary social goods, in the context of foreign horizons. Consequently, understanding and crossing horizons increases the likelihood that citizens will feel respected and will in turn respect the rule of law. Rights themselves should be perceived not merely as statements of ideals or entitlements but as goals to be pursued and as tools to be used in pursuit of those goals. Rights should be perceived and used as tools in the context of horizons, as means for crossing horizons, for pursuing law reform and should be understood from various perspectives or points of view including those of a judge and law reformer. Rights then are tools for hammering on foreign horizons, advancing the rule of law, and enhancing the legitimacy of a society.

From the perspective of a legal philosopher reflecting on the history of law and social change with a view to framing tools for lawyers and decision makers and engaged in developing judicial decision making method, I have argued in my book, $A$ Personalist 
Jurisprudence, The Next Step, that recognizing the interrelation between the concepts just reviewed is remarkably helpful. In this paper, I offer a discussion of these concepts and their relationship in honor of Dr. Richard Schwartz and to those concerned with understanding social change facilitated by law as a means for advancing a global rule of law and enhancing human rights.

Whether it is possible or helpful to use these concepts and their interrelation from the point of view of a social scientist studying law and social change, I leave to those educated in that foreign horizon and hence more knowledgeable than me. 